\title{
Entrepreneurial Success: Key Challenges Faced by Malaysian Women Entrepreneurs in 21 st Century
}

\author{
Abdul Basit ${ }^{1}$, Sze Wong ${ }^{2}$, Zubair Hassan ${ }^{1} \&$ Sharmila Sethumadhavan ${ }^{1}$ \\ ${ }^{1}$ IUMW Business School, International University of Malaya-Wales, Kuala Lumpur, Malaysia \\ ${ }^{2}$ International Consulting \& Training, Kuala Lumpur, Malaysia \\ Correspondence: Zubair Hassan, IUMW Business School, International University of Malaya-Wales, Jalan Tun \\ Ismail, Level 2, Block A, City Campus, 50480, Kuala Lumpur, Malaysia. E-mail: \\ zubai7@gmail.com/zubair@iumw.edu.my
}

Received: June 20, 2020

Accepted: August 3, 2020

Online Published: August 16, 2020

doi:10.5539/ijbm.v15n9p122

URL: https://doi.org/10.5539/ijbm.v15n9p122

\begin{abstract}
The purpose of this research is to investigate the challenges faced by women entrepreneurs on entrepreneurial success in Malaysia. This study proposes a conceptual framework and investigates the significant factors of family and social support, emotional intelligence, gender stereotype, and knowledge and risk-taking behavior in predicting women entrepreneurial success. Data was collected using a questionnaire with a Likert scale from 1-5 from a sample of 125 women entrepreneurs who owned Small-Medium-Enterprises (SME) in Malaysia using a convenient sampling technique. Collected data were analysed using structural equation modeling (SEM) via AMOS 22 software. The result indicated that "knowledge" have significant negative impact on women entrepreneurial success, while all the other challenges identified in the previous research such as lack of emotional intelligence, lack of family support, poor risk taking behaviour, gender stereotype were not significant in influencing women entrepreneurial success. Family and social support, and risk-taking behaviour were found contradict with other previous researches indicating that women entrepreneurs are becoming more independent due to the changing norms and cultural values. In conclusion, women entrepreneurial success largely dependent on the work experiences, relevant skills/competencies and industrial know-how they acquired and mastered to effectively manage and grow their businesses. It is recommended that women-entrepreneurs in Small Medium Enterprises(SME) shall invest in continuous learning to gain more relevant skills/competencies, knowledge, industrial know-how and experiences to sharpen their competitive advantages and sustain continuous development and growth. Therefore, it's highly recommended that government should formulate policies to promote women entrepreneurship through effective and practical trainings. This study will be useful for women entrepreneurs to develop themselves by investing themselves to gain knowledge by participating academic programs and industrial based network conferences. Entrepreneurial development authorities or bodies will be able to use this study to develop and design human resource development intervention program to enable women entrepreneurs to be more successful. Future researchers can increase the sample size and focus on similar type of small medium enterprise owners in terms of sector or industry and size. Also the future researchers can used a mixed method in collecting data to provide a more coherent and meaningful conclusion
\end{abstract}

Keywords: women entrepreneurs, entrepreneurial success, gender stereotype, emotional intelligence, family support, risk taking behaviour

\section{Introduction}

\subsection{Research Background}

Entrepreneurship was first mentioned in 17th century by economic thinker Richard Cantillon (1755), but the term was mainly reserved for men. Women-entrepreneurs were widely accepted beginning the 19th century with the rise of feminism, then the 21st century with availability of internet and technology as it that allowed women to be more prevalent in business world. In comparison with men-entrepreneurs worldwide, women-entrepreneurs tend to own smaller size of business ventures (Winn, 2005), their business development lagging behind and women have lower growth expectations and higher business discontinuance compare to men entrepreneurs (Brush, Carter, Gatewood, Greene, \& Hart, 2006). 
Over the past decades, women-owned-business had increased significantly (Carter \& Shaw, 2006), however women entrepreneurs' participation is still lower than $1 / 3$ compare to men entrepreneurs worldwide (Reaves, 2008). The reason men-entrepreneurs are more than women-entrepreneurs, being that men are responsible for the main household income, while women encounter work-home conflict and more stress and the need to strike a work-life balance running both business and family responsibility (Stanger, 1990). However, Farhat and Mijid (2018) revealed in their research that with the same human capital, preferences and industrial-clusters, women-entrepreneurs do not lag behind men-entrepreneurs as they have same survival and growth rates as well as profits generation.

Tambunan (2009) found women-entrepreneurs in Asia like India, Pakistan, Nepal, Bangladesh, Korea and South East Asia countries mostly run micro-enterprises (MIEs) with easy entry that required low capital, skills and technology. In the Malaysian context, there is no exception as most societies in the world remain male-controlled in business world. Based on World Economic Forum (2016), economic and political participation by women in Malaysia is highly unequal, ranked 106/144 at almost the lowest quartile (Hussein 2016). Several researchers revealed that in Malaysia the lack of institutional support given to women-entrepreneurs such as, macro-environmental issues remain barriers to their success (Mason \& Ibrahim 2012; Rashid et. al. 2015). On the other hand, Tanusia et. al., (2016) identified government support for women-owned-businesses was indeed an enabler of women-entrepreneurial success but women-entrepreneurs were found to have a lack of knowledge, skills and social network to support their businesses in Malaysia.

There are thoughtful disparities and deficits on problems faced by women-entrepreneurs globally. The six significant challenges faced by women entrepreneurs across the globe are lack of venture-capital, lack of self-belief, socio-cultural restrictions, regulatory restrictions, fear of failures and lack of education. Researchers determined women-entrepreneurs' the challenge that limit their success were mostly due to gender stereotype, lack of family and social support, weak personality traits, lack of education and knowledge (OECD, 2004; Bajpai, 2014;Krishnamoorthy \& Balasubramani, 2014; Bhardwaj, Parashar, Pandey, \& Sahu, 2012) There are evidence from developing countries and emerging markets that prove women-entrepreneurs' significant contribution in promoting business economically, socially and ecologically (Ambepitiya, 2016). In Malaysia the quality of women-entrepreneurs is said to be realistic, sensitive, visionary, cultured, customer-oriented, empowering, trusting and self-actualizing. There are many successful and inspiring Malaysian women-entrepreneurs that have broken the glass ceiling and made it big in their related fields and contributed to the nation. However, it can be understood in Malaysia that women entrepreneurs had been discouraged in being successful and achieve their dreams through different factors. Also the key challenges such as family and social support, emotional intelligence, gender sterotypes knolwdge and risk taking behaboour are given less importance despite these challenges hinders the women enterpreburial success, partcicularly in Malaysia. Also there is evidence that these challenges were simultaneously tested in this current study. Therefore, this research develops the following objectives below to examine the challenges faced by women-entrepreneurs in Malaysia.

\subsection{Research Objectives}
$\checkmark$ examine the impact of family and social support on women entrepreneurial success
$\checkmark$ examine the impact of emotional intelligence on women entrepreneurial success
$\checkmark$ examine the impact of gender stereotype on women entrepreneurial success
$\checkmark$ examine the impact of knowledge on women entrepreneurial success
$\checkmark$ examine the impact of risk-taking behaviour on women entrepreneurial success

\section{Literature Review}

\subsection{Review of Key Concept}

Women-entrepreneurs are regarded as individuals who has self-initiative and inner-drive to start their own business (Starr \& Yudkin, 1996). Whereas, Moore \& Buttner, (1997) described women-entrepreneur as leader who initiate business venture, manage day-to-day risk and operation, handle financial, coordinate administrative and hold up social responsibilities. Over few centuries and up until 20th century, women-entrepreneurs operate small-businesses to supplement income and survive the hardship like economic depression (Buttner, 1993). Women's entry into entrepreneurship was out of necessity more than men who based it on opportunity (Terjesen \& Amorós, 2010). As such, Lee, \& Venkataraman, (2006) defined entrepreneurship as a search process for alternatives or new opportunities. With dynamic macro and micro-environmental rapid changes in new economy, women-entrepreneurs shall be comprehended as risk-taker, continual-learner, influential-leader, great-manager and well-organizer with visionary, innovative-creation, conscientiousness, values-driven and social 
responsibilities (Kerr, Kerr, \& Xu, 2017).

Entrepreneurial success was mostly defined through tangible elements and economic perspective such as revenue growth, turnover, profitability, sustainability, personal wealth (Perren, 1999). Masuo, Fong, Yanagida, \& Cabal, (2001) defined entrepreneurial success in terms of financial measurement (sales, profits, returns, employees) and non-financial measurement (customer satisfaction, personal development). However, it does not suffice to restrict women-entrepreneur's success to only economic aspects as it does not explain the women's entrepreneurial behaviours. Women's success can be described in terms of their children, work-satisfaction, quality of life, contribution to community (Fenwick \& Hutton, 2000), being in control of their own destiny, building ongoing relationship with customers and self-fulfilment (Romano, 1994). However, many researchers also assumed there is no difference between women-entrepreneurs and men-entrepreneurs as successful entrepreneurs share the same motivation, success reasons and challenges and secure funding (Jennings \& Brush, 2013). Hence, women-entrepreneurial success should be measure in both financial and non-financial aspects to avoid success measurement biasness (Powell \& Eddleston, 2013).

Many researchers found that work-life balance is the most significant challenge faced by women-entrepreneurs (Neider, 1987; Lee-Gosselin \& Grise, 1990) as women-entrepreneurs found it challenging to handle multi-roles and grow their business at the same time and not spending enough time with their families (Alam, Jani, \& Omar, 2011). In many developing countries, home and family are the first priority of women (Shmiln, 2017). Social-cultural barriers faced by women-entrepreneurs were work-family balance and negative society perceptions in China (Berg \& Englund, 2015); gendered-inequality in Bangaldesh (Ferdousi \& Mahmud, 2019); patriarchal-society in Pakistan (Gillani, 2004). Family and social support has been identified as significant factor contributing to women-entrepreneurial success (Abbas, Abrar, Saleem, \& Iqbal, 2016). In the 21st century, the key factor driving women to be successful entrepreneurs were the ability to gain more flexibility and control over work-home obligations. (Agarwal \& Lenka, 2015).

Emotional intelligence is also considered as one of the key elements that women entrepreneurs find it difficult in managing. Salovey and Mayer (1990) defined emotional-intelligence as the ability to recognise and understand own and other's emotions, and to use the emotions to guide one's thinking and behaviours to effectively discriminate and regulate emotions towards achieving goals. Emotional-intelligence were applied to women-entrepreneurship and associated with leadership in the 20th century (Rhee \& White, 2007). Usha Rani and Menezes (2016) found women-entrepreneurs with high-level of emotional-intelligence demonstrated self-confidence, achievement and service-orientation, trustworthiness, collaboration and teamwork. Research by Swanson, Akwaowo, Zobisch, \& Leventhal, (2018) indicated strong relationship between emotional-intelligence and women-entrepreneurial success as a result of the ability to build and maintain personal and business relationships. However, there is no gender differences found in emotional-intelligence for entrepreneurial success (Ngah \& Salleh, 2015).

According to Cohoon, Wadhwa, \& Mitchell, (2010), access to initial capital is one of the top challenges faced by any entrepreneur, but women are more likely to face difficulty in securing funds and getting social support compare to men entrepreneurs. Karif, (2009) found that the women-owned-business and men-owned-business success had no direct relation with gender stereotype but their managerial performance does shape their business success. Despite women-entrepreneurs manifesting behaviours that contributed to leadership-effectiveness, they were perceived differently by male-counterparts (Eagly, 2013). In today's world with social progression, it's concluded gender-inequality on opportunity and social support still exist despite significant closer gap on gender-equality in education found with women's educational attainment exceeding men in some countries.

Knowledge is a set of structured/contextual information, values and experiences inclusive competencies that facilitates decision-making, problem-solving and behaviours in line with values (Garcia-Palma \& Molina, 2016). Women-entrepreneurs' lack of education/skills is one of the key challenges to grow their businesses, identified by many past researches worldwide regardless of its economical situations inclusive. However, it has been discovered that women enter into business with less formal business-specific education or work experiences compared to men, but women-entrepreneurs unanimously indicated their desires for learning opportunity to become more effective in leadership and management. Knowledge is continuous-learnable, competencies, skills and experiences that can help women-entrepreneurs to improve capabilities and reduce their stress towards achieving their goals (Tatar, 2014).

Janney and Dess (2006) conceptualised risk into three categories being variance (financial leverage variance), opportunity costs (foregoing profitable opportunities) and downside loss (negative outcome of decision/hazard). Women-entrepreneur's risk-taking behaviour is measured based on risk-propensity of which their determination 
and perseverance traits allow them to possess higher risk-propensity (Gartner, 1990). Many researchers found women-entrepreneurs not as much willing to venture into unknown new markets due to lack of risk attitude, less optimism, fear of failure, perceived lack of self-efficacy and have lower ability to take risk and adapt changes compare to men entrepreneurs. On the other hand, Kozubíková, Dvorský, Cepel, \& Balcerzak, 2017) appraised that women-entrepreneurs are more cautious risk-takers to minimize financial risks through building-up reserves.

Based on the literature review in Malaysia and the global context, firstly, it's arguable that majority researchers were focusing on mainly gaining perspective from comparing women and men entrepreneurs could be bias and may not reflect the reality, as empirical evidences explained much on gender-inducted differential performance without actual justification of such features explained gendered performance remain unanswered (Aldás-Manzano, Martínez-Fuentes, \& Pardo-del-Val, 2016). Secondly, the evidences were based upon self-reporting approaches which potentially raised social-desirability-response-bias that particularly salient in developing countries (Bernardi, 2006). Thirdly, it was identified that majority researcher's emphasis on different critical factors, and there is a lack of empirically validation which critical factors have a dominant effect on women-entrepreneurial success, and no existing study has empirically examined the various critical variables in the same conceptual framework to weight their impacts on women-entrepreneurial success. This meant that there is a need to analyse women-entrepreneurial success through multiple lens.

The below conceptual framework had been suggested after reading several empirical studiesState why the problem deserves new research. For basic research, the statement about importance might involve the need to resolve any inconsistency in results of past work and/or extend the reach of a theoretical formulation. For applied research, this might involve the need to solve a social problem or treat a psychological disorder. When research is driven by the desire to resolve controversial issues, all sides in the debate should be represented in balanced measure in the introduction. Avoid animosity and ad hominem arguments in presenting the controversy. Conclude the statement of the problem in the introduction with a brief but formal statement of the purpose of the research that summarizes the material preceding it. For literature reviews as well as theoretical and methodological articles, also clearly state the reasons that the reported content is important and how the article fits into the cumulative understanding of the field.

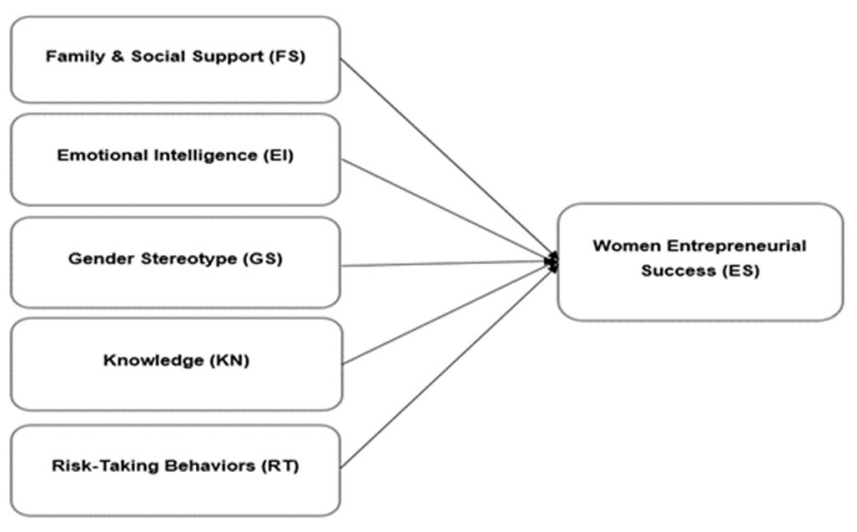

Figure 1. Conceptual framework

Women-entrepreneurs found difficulties and stress in balancing their work and family life as they were unable to spend enough time with their family due to work commitments (Alam, Senik, \& Jani, 2012); juggled multi-roles and faced work-family conflict with heavy household chores burden, childcare and children education (Loveline, 2014), which have negative and significant impact on women-entrepreneurial success. Shelton, (2016) revealed women-entrepreneurs who developed high-growth venture were capable in managing their work-life balance effectively through utilising role-sharing strategies to reduce their inter-role conflicts. Women-entrepreneurs found higher challenges to gain moral support and encouragement from their family and friends in venturing business as it leads to increase personal problems due to family authority and power to business interference (Welsh, Memili, \& Kaciak, 2016). Women entrepreneurs also found challenges in obtain financial capital from external sources like bank, venture-capital, investors and their business mainly funded by their family and friends due to their perceptions and goals on growth perspective and gendered-biasness (Fernandes, \& Mota-Ribeiro, 2017). A study conducted by Hahn, Minola, Bosio \& Cassia, (2019) found that family support has 
a positive effect on start-up activities negative capital market void can be overcome by family financial support.

\section{H1: Family and Social Support has significant impact on Women Entrepreneurial Success.}

Many researchers suggested women-entrepreneurs found less self-confidence, less optimism and higher fear of failure personality traits which has negative relations with performance but there is no proof of performance measurement link with their emotional-intelligence (Aldás-Manzano et al., 2012). Regulation and utilisation of emotions positively affect entrepreneurial self-efficacy (Mortan, RipollCarvalho, \& Bernal, 2014) and has a strong impact on innovativeness and entrepreneurial success as emotional-intelligence helps create competitiveness in negotiation, leadership and build customer-relationship (Ngah \& Salleh, 2015). Women-entrepreneurs were identified with lower self-esteem and self-efficacy in business decision-making (Pollack, Burnette, \& Hoyt, 2012), but in Schneider's (2017) study analysis it was found that entrepreneurial self-efficacy adaptation has greater contribution to women-entrepreneurial success. While women-entrepreneurs' aggressiveness, competitiveness and proactive behaviours (self-motivation and self-management in EI) lead them to less rational decision-making (Ürü, Çalskan, Atan, \& Aksu, 2011), evidences showed women-entrepreneurs were more emotional which overlapped their professional factors and affected their business development (Nassif, Andreassi, \& Tonelli, 2015).

\section{H2: Emotional Intelligence has significant impact on Women Entrepreneurial Success.}

Women-entrepreneurs were found less successful than men-entrepreneurs in many business aspects due to constraints in start-up capital, human-capital and business experiences (Fairlie \& Robb, 2009). Ylinenpää, \& Chechurina, (2000) in their study revealed challenges with patriarchal society structure limits women-entrepreneurial success as they were blamed for not taking-care of family and household. Women-entrepreneurs were generally perceived less ambitious than men-entrepreneurs due to gender-differences in risk, competitive and social preferences. (Minniti, 2010), stated whereby women-entrepreneurs are more risk-averse, less confidence and perceives risks as threats as opposed to challenges (Croson \& Gneezy, 2009). Hence, owning lower growth firms with lower profitability (Bardasi, Sabarwal, \& Terrell, 2011) findings shows successful women-entrepreneurs are confidence, resilience, passionate, with leadership skills and single-mindedness that helped to scale their businesses. A research conducted by Yacus, Esposito, \& Yang, (2019) found that women entrepreneurs are less likely to get finance for their business through debt finance compared to men entrepreneurs. A research also reveals that women entrepreneurs are more likely to be successful in feminine based industries than in non-feminine based industries owned by women entrepreneurs.

\section{H3: Gender Stereotype has significant impact on Women Entrepreneurial Success.}

Many studies identified women-entrepreneurs lacking business/management skills (Mauchi, 2014), work-experiences (Prasad, Naidu, Kinnera Murthy, Winkel, \& Ehrhardt, 2013) and industrial-specific knowledge (Zhou, 2010) that restrict their business growth and create hurdle for success. Women-entrepreneurs especially those running family and small businesses were unlikely to have prior work experience, hence have less opportunities to acquire human capital that critically impact their business success (Fairlie \& Robb, 2009). Technical competencies are critical expertise to facilitate implementation of women-entrepreneurs' vision and strategy. However, Loscocco, Robinson, Hall, \& Allen (1991) argued women-entrepreneurs were less successful namely being influenced by structural position as women-entrepreneurs tend to operate less-profitable industries and smaller-size businesses. Lack of education was not a problem for women-entrepreneurs according to Aslam, Latif, \& Aslam, (2013), instead, self-confidence about having skills/knowledge/experiences to run the business is a significant driver for successful women-entrepreneurship (Krueger Jr, Reilly, \& Carsrud, 2000). The formal and informal training about the products/services or mentorship plays a significant role in the success or failure of the business, is therefore recommend that women entrepreneurs acquire knowledge to be successful in the field (Sousa, Carmo, Gonçalves, Cruz, \& Martins, 2019).

\section{H4: Knowledge has significant impact on Women Entrepreneurial Success.}

Risk-taking behaviour and innovation significantly impact women-entrepreneurs' need for achievement to be competitive. (Wanjau, Wambugu, \& Mung'atu, 2015; Amah \& Okoisama, 2017). Women-entrepreneurs were found more risk-averse than men-entrepreneurs with evidences of gender-differences identified in women-entrepreneurs were; to react more emotionally to uncertain situations that determined their risk-taking behaviour as it affects the probability and outcomes evaluations (Croson \& Gneezy, 2009). Women-entrepreneurs have less confidence that lead to different risk-perceptions in their risk-preferences (Brindley, 2005). However, high risk-propensity (risk-taking-behaviour) was tested by Lammers, Willebrands, \& Hartog, (2010) with negative effect on profits but high risk-perception (perceived-risky-decision) has positive effect on profits. There is no gender-difference impact on performances as entrepreneurs with risk-taking and 
decisiveness traits took calculated-risk and minimized negative impact of financial risk through reserves (Kozubíková et. al. 2017). Indeed, women-entrepreneurs are more calculated risk-takers as they feel business-risks shall be assessed, calculated and managed well (Bose, 2016).

\section{H5: Risk-Taking Behaviour has significant impact on Women Entrepreneurial Success.}

\section{Material and Method}

\subsection{Target Population}

The target population of this study is women entrepreneurs of small medium enterprises (SME) in Malaysia. As small-medium-enterprises (SMEs) covers $98.5 \%$ of Malaysia business establishments, we use Malaysia SMEs' women-entrepreneurs as the criteria and condition to enhance the research validity for convenience sampling (Farrokhi \& Mahmoudi-Hamidabad, 2012). Hence, random sampling of total 186,855 Malaysia women-entrepreneur populations will not be employed as this study sample due to its irrational huge size of SMEs women-entrepreneurs population (Hasan, 2011).

In this study, the homogenous target populations of Malaysia SME's women-entrepreneurs is employed as this research purpose does not review the different ethnic, religious, age, socioeconomic or business size. This study employs the definition of SME (Figure 6) provided by National SME Development Council (NSDC) in Malaysia, the new SME definition was endorsed at the 14th NSDC, covers all sectors inclusive manufacturing, services, construction, agriculture, mining and quarrying.

\subsection{Sample Size and Sampling}

The acceptable sample size for a study depends on the research types such as descriptive, experimental or correlational, $10 \%$ of the total population is recommended for descriptive research, while correlational research shall have at least 30 subjects/variables for relationship establishment (Gay \& Diehl, 1992). Determination of sample size for target population is based on the total population size, confidence level, margin of error and standard of deviation (Roscoe, 1975; Alreck \& Settle, 1995; Hill, 1998). Cochran, (1977) uses two formula: margin of error and alpha level to determine the sample size. Wersberg and Bowen, (1977) provided a table guide for acceptable level of sampling error related to sample size, in which 100 sample size is sufficient if the acceptable margin of error is 10\% maximum. Hill, (1998) established significance level of $5 \%$ for acceptable confidence level in most behavioural sciences while Roscoe (1975) indicated $10 \%$ as rule of thumb for acceptable confidence level.

Malaysia women-entrepreneurs total population of 186,855 is irrationally huge sample size for survey, and with $10 \%$ of total population (Gay \& Diehl, 1992) 18,685 sample size is still too big and expensive with much resource and time consuming to conduct. Hence, this study adopted the Cochran's, (1977) formula with $\mathrm{t}$-value $=1.96$ and alpha level $=.05$ as rule of thumb for over 120 sample size is sufficient when involves smaller target populations. This study deploys total sample size of 150 women-entrepreneurs from target population of Malaysia SMEs using convenience/self-selected sampling technique, in view there might be lesser returned responses expected.

In this study, 150 questionnaires were distributed and a sample of 125 respondents were used based on the completed questionnaire after the omission of questionnaires which are not fully completed or wrongly completed with multiple answers. This study has adopted non-probability convenience sampling. Convenience sampling is based on opportunities accessibility and availability (Abrams, 2010) of which responders from relevant women-entrepreneur associations are self-selected to take part in research on their own accord, subjects to voluntary (Sharma, 2017). 
Table 1. Illustration of sample size

\begin{tabular}{|c|c|c|c|}
\hline Women-Entrepreneurs Association & $\begin{array}{c}\text { No. of } \\
\text { Respondent Sent }\end{array}$ & $\begin{array}{l}\text { No. of Respondent } \\
\text { Received }\end{array}$ & $\begin{array}{l}\text { No. of Respondent } \\
\text { Accepted }\end{array}$ \\
\hline $\begin{array}{l}\text { Malaysia Women-Entrepreneurs Club } \\
\text { ( } 57,700 \text { Facebook members closed group) - received approval for joining } \\
\text { membership }\end{array}$ & 30 & 29 & 29 \\
\hline $\begin{array}{l}\text { Entrepreneurs Malaysia Social Club } \\
(9,000 \text { Facebook members closed group }) \text { - received approval for joining } \\
\text { membership }\end{array}$ & 30 & 25 & 23 \\
\hline $\begin{array}{l}\text { Kuala Lumpur Business Networking Club } \\
\text { (25,200 Facebook members closed group }) \text { - received approval for joining } \\
\text { membership }\end{array}$ & 30 & 26 & 25 \\
\hline $\begin{array}{l}\text { Malaysia Business Network Group } \\
(3,200 \text { Facebook members closed group) - received approval for joining } \\
\text { membership }\end{array}$ & 30 & 28 & 28 \\
\hline $\begin{array}{l}\text { SME Corp Malaysia (government organization }-24,585 \text { Facebook members } \\
\text { public group) - no approval requires to join the group }\end{array}$ & 10 & 6 & 5 \\
\hline $\begin{array}{l}\text { Women Entrepreneur Network Association (WENA NGO: 1,675 Facebook } \\
\text { members public group) - no approval requires to join the group }\end{array}$ & 10 & 8 & 8 \\
\hline $\begin{array}{l}\text { National Association of Women Entrepreneurs of Malaysia (NAWEM NGO: } \\
814 \text { Facebook members public group) - no approval requires to join the group }\end{array}$ & 10 & 8 & 7 \\
\hline TOTAL & 150 & 130 & 125 \\
\hline
\end{tabular}

\subsection{Respondent Profile}

A total of 150 questionnaires were distributed to women-entrepreneurs in Malaysia with only 125 valid and reliable respondents, totaling $83.33 \%$ data collected. Out of 125 respondents, $65.6 \%$ are ages of between $36-55$ and $32 \%$ are between $25-36$, which indicates that probably more women start their own businesses after they have accumulated some work experiences, with more social networks and motivated to achieve financial independence and work-life balance with flexibility.

There are also significant portion of young women-entrepreneurs in this study indicating they could be choosing entrepreneurship as a naturally desirable work alternative or due to limitation in their work options (Avolio 2012). Longevity measures entrepreneurial success (Karpak \& Topcu 2010), 52.8\% respondents have over 10 years business experiences, while $47.2 \%$ women-entrepreneurs are with their business experiences between $>3$ years to $<10$ years and indicating business survival $>3$ years is a sign of successfulness in women-entrepreneurship as seen in this study's respondents.

There are $45.6 \%$ women-entrepreneurs running medium-size enterprise with $>50$ employees, $54.4 \%$ belongs to micro and small-size enterprises with majority $40 \%$ micro in size $<10$ employees. $73.9 \%$ respondents are in services/others sector, $12.8 \%$ in manufacturing and $13.6 \%$ in retail sector.

\subsection{Research Instrument}

A Likert-scales questionnaire was developed, which comprises of 6 variables, and include 5 items under each variable along with 5 demographic questions. Clear, short and straightforward words are used to develop the questionnaires to ensure simple and easy to understand for respondents.

The below table 2 shows that dimensions of the item constructions and the sources where items are being adapted. 
Table 2. Item construction

\begin{tabular}{|c|c|c|c|c|}
\hline \multirow[t]{3}{*}{ Variables } & \multirow[t]{3}{*}{ Factor Items } & \multicolumn{2}{|c|}{ Normality } & \multirow[t]{2}{*}{ Factor Loading } \\
\hline & & \multirow{2}{*}{\multicolumn{3}{|c|}{ Skew. }} \\
\hline & & & & \\
\hline \multirow{5}{*}{$\begin{array}{l}\text { Family \& Social Support } \\
\text { (FS) }\end{array}$} & Work-life balance (FS1) & -.697 & .362 & .775 \\
\hline & Family and social affective support (FS2) & -.533 & -.315 & .772 \\
\hline & Social networking (FS3) & -.105 & -.058 & .261 \\
\hline & $\begin{array}{l}\text { Family and social instrument support } \\
\text { (FS4) }\end{array}$ & .043 & -.613 & .467 \\
\hline & $\begin{array}{l}\text { Household chores burden / work-family } \\
\text { conflict (FS5) }\end{array}$ & -.876 & .888 & .652 \\
\hline \multirow{5}{*}{$\begin{array}{l}\text { Emotional Intelligence } \\
\text { (EI) }\end{array}$} & Personal competencies (EI1) & -.609 & .003 & .545 \\
\hline & Self-management (EI2) & -.345 & -.534 & .663 \\
\hline & Social competencies (EI3) & -.087 & -.750 & .616 \\
\hline & Self-perception (EI4) & -.187 & -.758 & .686 \\
\hline & Problem solving ability (EI5) & .360 & -.497 & .586 \\
\hline \multirow[t]{5}{*}{ Gender Stereotype (GS) } & Negative gendered-perception (GS1) & .123 & -.466 & .671 \\
\hline & $\begin{array}{l}\text { Gendered-Inequality on resource access } \\
\text { (economic, education, social, human, } \\
\text { financial etc.) (GS2) }\end{array}$ & -.081 & -1.159 & .739 \\
\hline & $\begin{array}{l}\text { Gendered-biasness on given opportunities } \\
\text { (GS3) }\end{array}$ & -.250 & -.802 & .767 \\
\hline & Perceived lack of leadership (GS4) & -.433 & -.723 & .749 \\
\hline & $\begin{array}{l}\text { Gendered-attributes biasness (Ambitious, } \\
\text { decisiveness, authoritarian etc.) (GS5) }\end{array}$ & .181 & -.765 & .604 \\
\hline \multirow[t]{5}{*}{ Knowledge (KN) } & Business skills (K1) & -.896 & 1.838 & .631 \\
\hline & Lack of work experience (K2) & -.817 & 1.532 & .557 \\
\hline & Industry / technical know-how (K3) & -.789 & 1.279 & .690 \\
\hline & Learning opportunities (K4) & -.978 & 1.673 & .770 \\
\hline & Access to education (K5) & -.210 & -.662 & .074 \\
\hline Risk-Taking Behavior & Risk propensity (RT1) & .199 & -.377 & .533 \\
\hline \multirow[t]{4}{*}{ (RT) } & Risk-taking ability (RT2) & .181 & -.524 & .459 \\
\hline & Entrepreneurial orientation traits (RT3) & .545 & -.224 & .899 \\
\hline & Risk taking behavior (RT4) & .362 & -.416 & .886 \\
\hline & Risk attitude (RT5) & .331 & -.725 & .714 \\
\hline Women Entrepreneurial & Entrepreneurial traits (ES1) & -.045 & .367 & .536 \\
\hline \multirow[t]{4}{*}{ Success (ES) } & Knowledge (ES2) & -.513 & .590 & .643 \\
\hline & Family \& Social Support (ES3) & -.342 & .130 & .706 \\
\hline & Emotional Intelligence (ES4) & -.443 & .234 & .778 \\
\hline & Risk-Taking Behaviors (ES5) & -.292 & .136 & .610 \\
\hline
\end{tabular}

The normality of the items in the construction are mostly checked using skewness and kurtosis. Since the normality of the items GS2, K1, K2, K3 and K4 in terms of kurtosis violated the acceptable range of -1 to 1 , it was decided that the researcher conduct a validity and reliability test before proceeding with structural equation modelling (SEM).

Validity measures the constructs in question to determine the accuracy of the tests. Research validity is checked using convergent validity to examine if the survey is answering the way researcher wanted it to answer (Campbell \& Fiske 1959), as well as tested with discriminant validity to measure the correlations/covariance between factors, and the degree of differences between the construct/factor as well as between the overlapping contracts (Hair, Ringle, \& Sarstedt, 2014). Since the factor loading on each item of FS2, FS3, K5 and RT2 is less than 0.5 , it was decided to remove the items and conduct second-order confirmatory factor analysis (CFA). Since the first-order CFA failed to obtain satisfactory result, a second-order CFA was carried out to ensure the item construction obtained to ensure improvement reliability and validity of the item contract. The result is illustrated below 
Table 3. Item construction

\begin{tabular}{lllll}
\hline Indices Category & Index & Level of Acceptance & First-Order CFA Result & Second-order CFA result \\
\hline \multirow{2}{*}{ Absolute Fit } & Chisq & $\mathrm{P}<0.05$ & 0.000 & 0.000 \\
& RMSEA & $\leq 0.08$ & 0.071 & 0.073 \\
Incremental Fit & CFI & $>0.90$ & 0.816 & 0.846 \\
Parsimony Fit & Chisq/Df & $<3.0$ & 1.627 & 1.667 \\
\hline
\end{tabular}

Table 3 shows that second order CFA had improved in terms of CFI to achieve the desired CFI of 0.9. It is very close to 0.9 (0.846) suggest that all the 'fit indices' have achieved the desired model fitness requirement. This enabled the researchers to carry-out the SEM. The table below further shows that the factor loading met the loading criteria of 0.5 suggesting that all the items in the construct are convergent valid (Hair, Ringle, \& Sarstedt, 2011).

The discriminant validity measurement result for this study indicates a comparably low levels of inter-construct correlations, neither approach points to discriminant validity problems. In squared correlations, result shows all constructs are below the threshold $<1.00$ as proposed by Hair et. al., (2011) with highest achieved 0.525 , indicates all contracts are valid and acceptable. Also, in terms of Average Variance Extracted (AVE) has met the requirement by exceeding the desired value of 0.5 (Hair et al, 2011).

In terms of reliability, it has improved after the modification of the item construction, as reliability of work and family support has increased from 0.713 to 0.781 . The Cronbach's Alpha value has improved for knowledge dimensions after the removal of K5 from 0.629 to 0.765 . Also, the Cronbach's Alpha value has improved for risk taking (RT) once RT2 has removed from 0.832 to 0.842 .

\section{Results}

To analyse the causal impact of challenges faced by women in their entrepreneurial success, the structural equation modelling was carried out. Prior to that the test was to ensure that SEM was valid in order to carry out the examination of causal impact of challenges faced by women entrepreneurs on women entrepreneurial success.

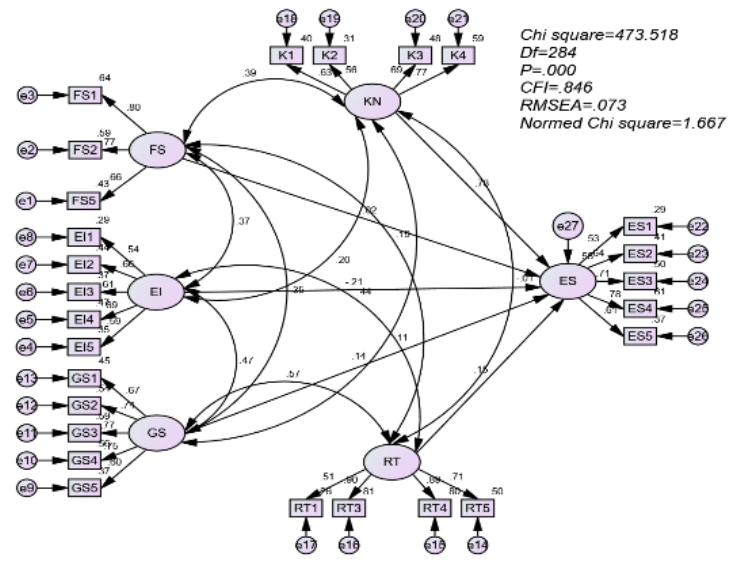

Figure 2. Structural equation model

A good way to test SEM validity is through the comparison of CFA measurement model and SEM structural model fit, as structural model is formed by the measurement model with added constraints, and if an insignificant chi-square test between these two models is found to provide empirical evidence for the proposed theoretical model.

The equivalent models shall produce the same estimated covariance matrix (Hair et al, 2011), of which in this study, the result of the factors loading for both models provide exactly the same results. The equivalent models shall produce the same estimated covariance matrix (Hair et. al., 2011), of which this study proves, the result of the factors loading for both models provide exactly the same results (Table 4) indicating a good fit of model with validity evidence from empirical results. 
Table 4. Equivalent fit for CFA and SEM models

\begin{tabular}{lllllll}
\hline & Chisq & Df & P-Value & CFI & RMSEA & Chisq/Df \\
\hline Rule of Thumb & & & $<0.05$ & $>0.90$ & $<=0.08$ & $<3.0$ \\
CFA Measurement Model (MM) & 473.518 & 284 & 0.000 & 0.846 & 0.073 & 1.667 \\
SEM Structural Model (SM) & 473.518 & 284 & 0.000 & 0.846 & 0.073 & 1.667 \\
\hline
\end{tabular}

Hair et. al., (2011) provides proof of structural model validity by comparing the factor loading in both measurement model and structural model with factors loading value $>0.50$ and indicates $100 \%$ similarity as rule of thumb for good model fit. The result shows for comparison of both models' factors loading are exactly the same indicates good model fitness suggesting that the SEM is valid. The below is the hypothesis results found in this research:

Table 5. Hypothesis testing results

\begin{tabular}{|c|c|c|c|c|c|c|c|}
\hline & & & & Estimate & S.E. & C.R. & $\mathrm{P}$ \\
\hline H1 & $\begin{array}{l}\text { Women } \\
\text { Entrepreneurial } \\
\text { Success }\end{array}$ & $\leftarrow$ & Family \& Social Support & .011 & .079 & .134 & .893 \\
\hline $\mathrm{H} 2$ & $\begin{array}{l}\text { Women } \\
\text { Entrepreneurial } \\
\text { Success }\end{array}$ & $\leftarrow$ & Emotional Intelligence & -.141 & .088 & -1.605 & .108 \\
\hline $\mathrm{H} 3$ & $\begin{array}{l}\text { Women } \\
\text { Entrepreneurial } \\
\text { Success }\end{array}$ & $\leftarrow$ & Gender Stereotype & -.088 & .083 & -1.068 & .286 \\
\hline $\mathrm{H} 4$ & $\begin{array}{l}\text { Women } \\
\text { Entrepreneurial } \\
\text { Success }\end{array}$ & $\leftarrow$ & Knowledge & -.661 & .157 & 4.211 & .000 \\
\hline H5 & $\begin{array}{l}\text { Women } \\
\text { Entrepreneurial } \\
\text { Success }\end{array}$ & $\leftarrow$ & Risk-Taking Behavior & .080 & .065 & 1.240 & .215 \\
\hline
\end{tabular}

This study does not support the hypothesis (H1) as its p-value 0.893 with estimate 0.011 indicates family and social support has insignificant positive impact on women-entrepreneurial success in Malaysia. Indeed, the result complies with the Business-Family-Interface Theory as family moral-support and roles-sharing was found essential to women-entrepreneurs but only plausible connection with women-entrepreneurial success, which support the research done by Vadnjal \& Vadnjal, (2013) and Welsh \& Kaciak, (2018). As Malaysian women-entrepreneurs are more independent now it is demonstrated that their capability in business-family balance as entrepreneurs, has become essential tool to empower women-entrepreneurs in achieving their desire lives, whilst open and modern Malaysian family no longer follow the typical patriarchal patterns.

This study does not support the hypothesis as its p-value 0.108 with estimate -0.141 indicates emotional intelligence has insignificant negative impact on women-entrepreneurial success. The result complies with Goleman's model that focuses emotional-intelligence on competencies/skills in driving performance (Goleman,2009). Result also complies with Baron Model that explains self-reporting scales of interconnected behaviours driven by emotional and social competencies influence behaviours and performances regardless of positive or negative. Also, in the past, studies show self-perception, self-motivation and self-management in emotional-intelligence are yielding negative impact towards women-entrepreneurial success but not significantly.

The Hypothesis (3) found p-value 0.286 with estimate value -0.088 indicating gender stereotype has insignificant negative impact on women-entrepreneurial success. The result doesn't comply with the Liberal-Feminist-Theory indicating women has ability in maintaining equality right and access to opportunities, as result the gendered-inequality still exist but doesn't significantly impact women-entrepreneurial success negatively. Result complies with the Role-Congruence-Theory indicating women are expected to behave in the way that match their social roles, prejudicing women less favourably in taking up leadership roles lacking of leadership behaviour (Eagly \& Karau, 2002),

The hypothesis (H4) supported by Gottschalk \& Niefart, (2013) in their past research identified knowledge with 
significant negative impact on women-entrepreneurial success. This study does support this hypothesis as its p-value $<0.001$ with estimate -0.661 indicates knowledge has highly significant negative impact on women-entrepreneurial success. It's in line with Tanusia et. al., (2016); research findings that knowledge/skills/experiences remain the top challenges towards women-entrepreneurial success in Malaysia. Result complies with the Kirzer's Alertness-Entrepreneurship-Theory indicating women-entrepreneurs utilise information for alertness to opportunities (Kaish \& Gilad 1991) are essential to be competitive in the market (Jong \& Marsili 2010), and knowledge/experiences with effects on opportunity identification and recognition has significant impact on women-entrepreneurial success (Cabrera \& Mauricio 2017). Result supports the findings from Chavali, (2016) and Holienka, Jančovičová, \& Kovačičová, (2016) that women-entrepreneurs have less ability towards alertness to opportunities due to cultural/structural restrictionshas significant negative impact on women-entrepreneurial success as gendered-inequality and gendered-biasness on opportunities to women-entrepreneurs in Malaysia found to have the most significant correlation coefficient with women-entrepreneurial success.

The hypothesis (H5) supported by Cronson \& Gneezy, (2009) and Sicard, (2016) in their past researches that revealed risk-taking-behaviour has significant negative effects on women-entrepreneurial success. The findings of this research found risk-taking behaviour has insignificant positive impact on women-entrepreneurial success. The results contradict with Nasip, Fabeil, Buncha, Hui, Sondoh, \& Abd Halim, (2017) research findings that risk-taking behaviour and self-confidence has significant positive impact on women-entrepreneurial performances in Malaysia. Fear of failure, lack of self-confidence, risk-propensity, creativity and innovative remains significant in predicting women-entrepreneurial success in this study's findings. The result complies with Knight's Approach as women-entrepreneurs with risk propensity and are calculated risk-takers demonstrating their business survivorship, longevity and economic performances (Kemkar \& Sharma, 2016).

\section{Conclusion}

\subsection{Conclusion}

Literature and empirical review indicate family and social support is one of the key factors that significantly and negatively impact women-entrepreneurial success with many supportive previous empirical studies, however, result of this study findings indicate family and social support has positive impact on women-entrepreneurial success but not significant and not an important factor. No doubt family and social support is an essential element to women-entrepreneurs, however, modern family, independent women and the information communication technology (ICT) evolves in the 21 st century has changed the traditional concept of family and social structure.

Also, more mature women-entrepreneurs and/or with mature business operations tend to have less concern on family and social support challenges. Hence, women-entrepreneurs would view family and social support important but not the determinant factor affecting their success. One of the key factors negatively and significantly affecting women-entrepreneurial success are that many women-entrepreneurs found with higher emotional incline, lack of self-confidence, self-efficacy and social competencies. But result shows the emotional intelligence negative impact is not significant or not considered critical factor affecting the women-entrepreneurial success. This implies entrepreneurs are naturally self-sufficient/self-supporting and have good internal self-control, they are distinctive from others as they are people who believe they can control their own destiny. Hence, it justified that most women-entrepreneurs do not find emotional intelligence impacting their entrepreneurial success significantly.

In terms of gender stereotype, is a critical factor that has significant negative impact on women-entrepreneurial success. However, result indicates negative social perception, gendered-inequality and stereotypically portrayed masculine entrepreneur roles towards women-entrepreneur disadvantageous still exist, but it's not significantly impacting women-entrepreneurial success. The reason why women-entrepreneurs do not take gender stereotype as critical factor affecting their success despite challenges persist are that as women are not focusing in competing with men in business ventures while they pursue different preferences, and view opportunities and success differently.

Also lack of knowledge negatively and significantly affects women entrepreneurs in their right resource acquisition decision; constrained their opportunity identification/recognition; undermined their development of crucial characteristics such as risk-taking, creativity and innovative; and affected women-entrepreneurs' self-confidence level and business success negatively. Generally risk-taking behaviour is one critical factor that significantly hinders women-entrepreneurial success. Hence, it's justifiable that existing or more mature women-entrepreneurs would find risk-taking behaviour not the most significant factor contributing to their 
venture success as it's the embedded characteristic in any entrepreneur where else non-entrepreneurs that intend to move into entrepreneurship or young women-entrepreneurs may find it differently.

\subsection{Implication and Recommendations}

This study indicates that women-entrepreneurial success largely dependent on the work experiences, industrial know-how, relevant business and management skills/competencies that they acquired and mastered to effectively develop, manage and grow their businesses. With the dynamic changing macro-environment, it's highly recommended that women who wish to enter into entrepreneurship venture, new start-ups, and/or young women-entrepreneurs first acquire the essential working experiences, skills and industrial know-how considered taken calculated risks and getting family and social support are essential in gaining self-confidence in making the venture successful in the early stages of business with the least requirement of sustaining business survivorship of more than three years.

Women-entrepreneurs who wish to sustain long-term business development and growth, need continuous learning and participation in relevant training as essential driver for entrepreneurial success to unleash innovative and creative sharpening of the competitive advantages to outcompete in the market. As this research indicates that emotional intelligence and gender stereotype have negative impact on women-entrepreneurial success, of which negative social perceptions, gendered-inequality, and self-regulation of emotions could possibly affect women-entrepreneurs' instinct motivation, self-perceptions and self-confidence on their abilities in pursuance of excellence or breakthrough of the glass ceiling. Hence, women-entrepreneurs shall learn to be more mindful about the negative emotions especially dealing with critical problem-solving and/or decision-making. When in dealing with changes, learning is one of the most crucial and powerful ways that support and strengthen one's intrinsic motivations, beliefs and self-confidence in making positive transformation. Hence, learning would be a good repositioning strategy in dealing with vulnerable.

The result of this study will assist government and/or relevant women-entrepreneurs non-government organizations (NGO) to identify the critical success factors for women-entrepreneurs in Malaysia. Women entrepreneurs are not existing to replace the patriarchal roles of masculinity but as complimentary to the social and economic developments. As women-entrepreneurs have proven significant contributions to the nations' sustainable development of economic-prosperity, environmental-equality, social-justice, and elimination of poverty in provision of employment opportunities in many countries contributing to significant growth in the nations' GDP, Malaysia government and interested NGOs are urged to promote women-entrepreneurship through offers in a variety of effective and practical training as well as exposure through cross-border's learning to support women-entrepreneurs to create competitive advantage in their business ventures.

\section{References}

Abbas, T., Abrar, M., Saleem, R., \& Iqbal, A. (2016). What Leads to Success for Women Entrepreneurs? An Empirical Study of Southern Punjab in Pakistan.

Abrams, L. S. (2010). Sampling 'hard to reach' populations in qualitative research: The case of incarcerated youth. Qualitative Social Work, 9(4), 536-550. https://doi.org/10.1177/1473325010367821

Agarwal, S., \& Lenka, U. (2015). Study on work-life balance of women entrepreneurs-review and research agenda. Industrial and Commercial Training. https://doi.org/10.1108/ICT-01-2015-0006

Alam S. S., Jani, M. F. M. \& Omar N. A. (2011). An empirical study of success factors of women entrepreneurs in southern region in Malaysia. International Journal of Economics and Finance, 3(2), 166-175. https://doi.org/10.5539/ijef.v3n2p166

Alam, S. S., Senik, Z. C., \& Jani, F. M. (2012). An exploratory study of women entrepreneurs in Malaysia: Motivation and problems. Journal of Management Research, 4(4), 282-297. http://dx.doi.org/10.5296/jmr.v4i4.2377

Aldás-Manzano, J., Martínez-Fuentes, C., \& Pardo-del-Val, M. (2012). Women Entrepreneurship and Performance. In Women's Entrepreneurship and Economics (pp. 89-108). Springer, New York, NY. https://doi.org/10.1007/978-1-4614-1293-9_7

Alreck, P. L., \& Settle, R. B. (1995). The Survey Research Handbook. Chicago: Richard D. Irwin.

Amah, E., \& Okoisama, T. (2017). Risk Taking nd Survival of Small and Medium Scale Enterprises in Nigeria. Archives of Business Research, 5(11). https://doi.org/10.14738/abr.511.3769

Ambepitiya, K. R. (2016). The Role of Women Entrepreneurs in Establishing Sustainable Development in Developing Nations. World Review of Business Research, 6(1), 161-178. 
Aslam, S., Latif, M., \& Aslam, M. (2013). Problems faced by women entrepreneurs and their impact on working efficiency of women in Pakistan. Middle-East Journal of Scientific Research, 18(8), 1204-1215. https://doi.org/0.5829/idosi.mejsr.2013.18.8.12406

Avolio, B. (2012). Why women enter into entrepreneurship? An emerging conceptual framework based on the Peruvian case. Journal of Women's Entrepreneurship and Education, (3-4), 43-63.

Bajpai, G. C. (2014). African women entrepreneur: Problems, challenges and future opportunities. International Journal of Managerial Studies and Research, 2(5), 17-22.

Bardasi, E., Sabarwal, S., \& Terrell, K. (2011). How do female entrepreneurs perform? Evidence from three developing regions. Small Business Economics, 37(4), 417.https://doi.org/10.1007/s11187-011-9374-z

Berg, S., \& Englund, M. (2015). Female Entrepreneurship in China. A comparative study of challenges between female and male entrepreneurs in China. Retrieved from https://gupea.ub.gu.se/bitstream/2077/39812/1/gupea_2077_39812_1.pdf

Bernardi, R. A. (2006). Associations between Hofstede's cultural constructs and social desirability response bias. Journal of Business Ethics, 65(1), 43-53. https://doi.org/10.1007/s10551-005-5353-0

Bhardwaj, G. N., Parashar, S., Pandey, B., \& Sahu, P. (2012). Women Entrepreneurship in India: Opportunities and Challenges. Research paper.

Bose S. (2016). Women Entrepreneurs Taking More Risks Than Men. Small Business Trends.

Brindley, C. (2005). Barriers to women achieving their entrepreneurial potential. International Journal of Entrepreneurial Behavior \& Research. https://doi.org/10.1108/13552550510590554

Brush, C. G., Carter, N. M., Gatewood, E. J., Greene, P. G., \& Hart, M. M. (2006). Women's entrepreneurship in the United States. Growth-Oriented Women Entrepreneurs and their Businesses: A Global Research Perspective, Cheltenham, UK and Northampton, MA, USA: Edward Elgar.

Buttner, E. H. (1993). Female entrepreneurs: how far have they come? Business Horizons-Bloomington, 36, 59-59.

Buttner, E. H., \& Moore, D. P. (1997). Women's organizational exodus to entrepreneurship: self-reported motivations and correlates with success. Journal of small business management, 35, 34-46.

Cabrera-Gil-Grados, E. M., \& Mauricio, D. (2017). Factors affecting the success of women's entrepreneurship: a review of literature. https://doi.org/10.1108/IJGE-01-2016-0001

Campbell, D. T., \& Fiske, D. W. (1959). Convergent and discriminant validation by the multitrait-multimethod matrix. Psychological bulletin, 56(2), 81.https://doi.org/10.1037/h0046016

Carter, S. L., \& Shaw, E. (2006). Women's business ownership: Recent research and policy developments.

Chavali, K. (2016). Dynamics of Women Entrepreneurs in Sultanate of Oman-Opportunities and Obstacles. International Review of Management and Marketing, 6(1).

Cochran, W. G. (1977). Sampling techniques (3rd ed.). Wiley. New York.

Cohoon, J. M., Wadhwa, V., \& Mitchell, L. (2010). The anatomy of an entrepreneur are successful women entrepreneurs different from men? The Ewing Marion Kauffman Foundation.

Croson, R., \& Gneezy, U. (2009). Gender differences in preferences. Journal of Economic Literature, 47(2), 448-74. https://doi.org/10.1257/jel.47.2.448

Dafna, K. (2008). Managerial performance and business success. Journal of enterprising communities: People and places in the global economy. https://doi.org/10.1108/17506200810913890

De Jong, J. P., \& Marsili, O. (2010). Schumpeter versus Kirzner: An empirical investigation of opportunity types. EIM Research Reports.

Eagly, A. H. (2013). Women as leaders: Leadership style versus leaders' values and attitudes. In Gender and work: Challenging conventional wisdom. Harvard Business School Press.

Eagly, A. H., \& Karau, S. J. (2002). Role congruity theory of prejudice toward female leaders. Psychological review, 109(3), 573.

Fairlie, R. W., \& Robb, A. M. (2009). Gender differences in business performance: evidence from the Characteristics of Business Owners survey. Small Business Economics, 33(4), 375. https://doi.org/10.1007/s11187-009-9207-5 
Farhat, J., \& Mijid, N. (2018). Do women lag behind men? A matched-sample analysis of the dynamics of gender gaps. Journal of Economics and Finance, 42(4), 682-709. https://doi.org/10.1007/s12197-017-9416-8

Fenwick, T., \& Hutton, S. (2000). Women crafting new work: The learning of women entrepreneurs. In Proceedings of 41st Annual Adult Education Research Conference, Vancouver, Canada: University of British Columbia (pp. 127-132).

Ferdousi, F., \& Mahmud, P. (2019). Role of social business in women entrepreneurship development in Bangladesh: perspectives from Nobin Udyokta projects of Grameen Telecom Trust. Journal of Global Entrepreneurship Research, 9(1), 58. https://doi.org/10.1186/s40497-019-0184-0

Fernandes, E., \& Mota-Ribeiro, S. (2017). "Respect" and "self-determination” women entrepreneurs' identities and entrepreneurial discourses. Gender in Management: An International Journal. https://doi.org/10.1108/GM-04-2016-0093

García-Palma, M. B., \& Molina, M. I. S. M. (2016). Knowledge and female entrepreneurship: A competence and social dimension. Suma de Negocios, 7(15), 32-37. https://doi.org/10.1016/j.sumneg.2015.12.005

Gartner, W. B. (1990). What are we talking about when we talk about entrepreneurship? Journal of Business venturing, 5(1), 15-28. https://doi.org/10.1016/0883-9026(90)90023-M

Gay, L. R., \& Diehl, P. L. (1992). Research Methods for Business and Management.

Gilani, S. M. (2004). Impediments for Women Entrepreneurship Development. Lahore School of Economics.

Goleman, D. (2009). Working with emotional intelligence. A\&C Black.

Gottschalk, S., \& Niefert, M. (2013). Gender differences in business success of German start-up firms. International Journal of Entrepreneurship and Small Business, 18(1), 15-46. https://doi.org/10.1504/IJESB.2013.050750

Hahn, D., Minola, T., Bosio, G., \& Cassia, L. (2019). The impact of entrepreneurship education on university students' entrepreneurial skills: a family embeddedness perspective. Small Business Economics, 1-26. https://doi.org/10.1007/s11187-019-00143-y

Hair Junior, J. F., Hult, G. T. M., Ringle, C. M., \& Sarstedt, M. (2014). A primer on partial least squares structural equation modeling (PLS-SEM).

Hair, J. F., Ringle, C. M., \& Sarstedt, M. (2011). PLS-SEM: Indeed a silver bullet. Journal of Marketing theory and Practice, 19(2), 139-152.https://doi.org/10.2753/MTP1069-6679190202

Hill, R. (1998). What sample size is "enough" in internet survey research. Interpersonal Computing and Technology: An electronic journal for the 21st century, 6(3-4), 1-12.

Holienka, M., Jančovičová, Z., \& Kovačičová, Z. (2016). Drivers of women entrepreneurship in Visegrad countries: GEM evidence. Procedia-Social and Behavioral Sciences, 220, 124-133. https://doi.org/10.1016/j.sbspro.2016.05.476

Hussein, N. (2016). Women are valuable resource for economic development. The Star Online.

Janney, J. J., \& Dess, G. G. (2006). The risk concept for entrepreneurs reconsidered: New challenges to the conventional wisdom. Journal of Business Venturing, 21(3), 385-400. https://doi.org/10.1016/j.jbusvent.2005.06.003

Jennings, J. E., \& Brush, C. G. (2013). Research on women entrepreneurs: challenges to (and from) the broader entrepreneurship literature? The Academy of Management Annals, 7(1), 663-715. https://doi.org/10.1080/19416520.2013.782190

Kaish, S., \& Gilad, B. (1991). Characteristics of opportunities search of entrepreneurs versus executives: Sources, interests, general alertness. Journal of Business Venturing, 6(1), 45-61. https://doi.org/10.1016/0883-9026(91)90005-X

Karif, D. (2009). Managerial Performance and Business Success: Gender Differences in Canadian and Israeli Entrepreneurs. HEC Montréal, Chaire d'entrepreneuriat Rogers-J.-A. Bombardier.

Karpak, B., \& Topcu, I. (2010). Small medium manufacturing enterprises in Turkey: An analytic network process framework for prioritizing factors affecting success. International Journal of Production Economics, 125(1), 60-70. https://doi.org/10.1016/j.ijpe.2010.01.001 
Kerr, S. P., Kerr, W. R., \& Xu, T. (2017). Personality traits of entrepreneurs: A review of recent literature (No. w24097). National Bureau of Economic Research. https://doi.org/10.3386/w24097

Kozubíková, L., Dvorský, J., Cepel, M., \& Balcerzak, A. P. (2017). Important characteristics of an entrepreneur in relation to risk taking: Czech Republic case study. Journal of International Studies, 10(3), 220-233. https://doi.org/10.14254/2071-8330

Krishnamoorthy, V., \& Balasubramani, R. (2014). Motivational factors among women entrepreneurs and their entrepreneurial success: A study. International Journal of Management Research and Business Strategy, $3(2), 13-26$.

Krueger Jr, N. F., Reilly, M. D., \& Carsrud, A. L. (2000). Competing models of entrepreneurial intentions. Journal of Business Venturing, 15(5-6), 411-432. https://doi.org/10.1016/S0883-9026(98)00033-0

Lammers, J., Willebrands, D., \& Hartog, J. (2010). Risk attitudes and profits among small enterprises in Nigeria (No. 10-053/3). Tinbergen Institute Discussion Paper.

Lee, J. H., \& Venkataraman, S. (2006). Aspirations, market offerings, and the pursuit of entrepreneurial $\begin{array}{lllll}\text { opportunities. Journal of } & \text { Business }\end{array}$ https://doi.org/10.1016/j.jbusvent.2005.01.002

Loscocco, K. A., Robinson, J., Hall, R. H., \& Allen, J. K. (1991). Gender and small business success: An inquiry into women's relative disadvantage. Social forces, 70(1), 65-85. https://doi.org/10.1093/sf/70.1.65

Loveline, A. A., Uchenna, O. I., \& Karubi, N. P. (2014). Women entrepreneurship in Malaysia: an empirical assessment of the challenges faced by micro and small business owners in Kuching-Sarawak. International Journal of Humanities Social Sciences and Education, 4(1), 48-58.

Mason, C., \& Ibrahim, M. (2012). Challenges faced by Muslim women entrepreneurs: the Malaysian context. In International Conference on Business and Economic Research (pp. 2350-2359).

Masuo, D., Fong, G., Yanagida, J., \& Cabal, C. (2001). Factors associated with business and family success: A comparison of single manager and dual manager family business households. Journal of Family and Economic Issues, 22(1), 55-73. https://doi.org/10.1023/A:1009492604067

Mauchi, F. N. (2014). Challenges faced by women entrepreneuers: A case study of Mashonaland central province.

Minniti, M. (2010). Female entrepreneurship and economic activity. The European Journal of Development Research, 22(3), 294-312.https://doi.org/10.1057/ejdr.2010.18

MIWE, (2017). Mastercard Index of Women Entrepreneurs 2017. Newsroom Mastercard.

Mortan, R. A., Ripoll, P., Carvalho, C., \& Bernal, M. C. (2014). Effects of emotional intelligence on entrepreneurial intention and self-efficacy. Revista de Psicología del Trabajo y de las Organizaciones, 30(3), 97-104. http://dx.doi.org/10.1016/j.rpto.2014.11.004

Nasip, S., Fabeil, N. F., Buncha, M. R., Hui, J. N. L., Sondoh, S. L., \& Abd Halim, D. N. (2017). Influence of entrepreneurial orientation and social capital on business performance among women entrepreneurs along west coast Sabah Malaysia. In Proceedings of International Conference on Economics (pp. 377-393).

Nassif, V. M. J., Andreassi, T., \& Tonelli, M. J. (2016). Critical incidents among women entrepreneurs: Personal and professional issues. Revista de Administração (São Paulo), 51(2), 212-224. https://doi.org/10.5700/rausp1235

Neider, L. (1987). A preliminary investigation of female entrepreneurs in Florida. Journal of small business management, 25(3), 22.

Ngah, R., \& Salleh, Z. (2015). Emotional intelligence and entrepreneurs' innovativeness towards entrepreneurial success: A preliminary study. American Journal of Economics, 5(2), 285-290. https://doi.org/10.5923/c.economics.201501.3

OECD, (2004). Women 's Entrepreneurship: Issues and Policies, Promoting Entrepreneurship and Innovative SMEs in a Global Economy: Towards a More Responsible and Inclusive Globalization.

Perren, L. (1999). Factors in the growth of micro-enterprises (Part 1): Developing a framework. Journal of small business and enterprise development, 6(4), 366-385. https://doi.org/10.1108/EUM0000000006691

Pollack, J. M., Burnette, J. L., \& Hoyt, C. L. (2012). Self-efficacy in the face of threats to entrepreneurial success: Mind-sets matter. Basic and Applied Social Psychology, 34(3), 287-294. 
https://doi.org/10.1080/01973533.2012.674452

Powell, G. N., \& Eddleston, K. A. (2013). Linking family-to-business enrichment and support to entrepreneurial success: do female and male entrepreneurs experience different outcomes? Journal of business venturing, 28(2), 261-280. https://doi.org/10.1016/j.jbusvent.2012.02.007

Prasad, V. K., Naidu, G. M., Kinnera Murthy, B., Winkel, D. E., \& Ehrhardt, K. (2013). Women entrepreneurs and business venture growth: an examination of the influence of human and social capital resources in an Indian context. Journal of Small Business \& Entrepreneurship, 26(4), 341-364. https://doi.org/10.1080/08276331.2013.821758

Rashid, K. M., Ngah, H. C., Mohamed, Z., \& Mansor, N. (2015). Success factors among women entrepreneur in Malaysia. International Academic Research Journal of Business and Technology, 1(2), 28-36.

Reaves, B. B. (2008). Entrepreneurial success: A phenomenological study of the characteristics of successful female entrepreneurs. PhD diss. University of Phoenix, US. Retrieved from ProQuest (UMI 3338362).

Rhee, K. S., \& White, R. J. (2007). The emotional intelligence of entrepreneurs. Journal of Small Business \& Entrepreneurship, 20(4), 409-425. https://doi.org/10.1080/08276331.2007.10593408

Romano, C. (1994). It looks like men are from Mars, women are from Venus. Management Review, 83(10), 7-8.

Roscoe, J. T. (1975). Fundamental research statistics for the behavioral sciences [by] John T. Roscoe.

Salovey, P., \& Mayer, J. D. (1990). Emotional intelligence. Imagination, cognition and personality, 9(3), 185-211. https://doi.org/10.2190/DUGG-P24E-52WK-6CDG

Schneider, K. (2017). Entrepreneurial competencies of women entrepreneurs of micro and small enterprises. Science Journal of Education, 5(6), 252-261. https://doi.org/10.11648/j.sjedu.20170506.14

Sharma, G. (2017). Pros and cons of different sampling techniques. International journal of applied research, $3(7), 749-752$.

Shelton, L. M. (2006). Female entrepreneurs, work-family conflict, and venture performance: New insights into the work-family interface. Journal of small business management, 44(2), 285-297. https://doi.org/10.1111/j.1540-627X.2006.00168.x

Shmiln, A. W. (2017). Female entrepreneurs in developing countries: a comparative with developed countries as explorative study. Arabian J Bus Manag Review, 7(331), 2.

Showkat, N., \& Parveen, H. (2017). Non-Probability and Probability Sampling e-PG Pathshala. Media and Communication Studies, P2M16.

Sicard, B. (2017). What can Schumpeter tell us about women entrepreneurship in Iran? Journal of Entrepreneurship, Business and Economics, 5(1), 185-215.

Sousa, M. J., Carmo, M., Gonçalves, A. C., Cruz, R., \& Martins, J. M. (2019). Creating knowledge and entrepreneurial capacity for HE students with digital education methodologies: Differences in the perceptions of students and entrepreneurs. Journal of Business Research, 94, 227-240. https://doi.org/10.1016/j.jbusres.2018.02.005

Stanger, A. (1990). Female entrepreneurs in Australia: a review. Asia Pacific International Management Forum, 16(4), 12-20.

Starr, J., \& Yudkin, M. (1996). Women entrepreneurs: A review of current research (Vol. 15). Wellesley Centers for Women.

Swanson, A., Akwaowo, E., Zobisch, P., \& Leventhal, R. (2018). Emotional Intelligence and Entrepreneurs. Hawaii Global Conference on Business and Finance, 24(January), 1-1.

Tambunan, T. (2009). Women entrepreneurship in Asian developing countries: Their development and main constraints. Journal of Development and Agricultural Economics, 1(2), 27-40.

Tanusia, A., Marthandan, G., \& Subramaniam, I. D. (2016). Economic Empowerment of Malaysian Women through Entrepreneurship: Barriers and Enablers. Asian Social Science, 12(6). https://doi.org/10.5539/ass.v12n6p81

Tatar, G. A. (2014). How are entrepreneurial competence and dynamic capabilities of the Norwegian IT Start-ups related to performance.

Terjesen, S., \& Amorós, J. E. (2010). Female entrepreneurship in Latin America and the Caribbean: 
Characteristics, drivers and relationship to economic development. The European Journal of Development Research, 22(3), 313-330. https://doi.org/10.1057/ejdr.2010.13

Ürü, F. O., Çalskan, S. C., Atan, Ö., \& Aksu, M. (2011). How much entrepreneurial characteristics matter in strategic decision-making? Procedia-social and behavioral sciences, 24, 538-562. https://doi.org/10.1016/j.sbspro.2011.09.112

Usha Rani, M. R., \& Menezes, C. (2016). Hidden Drivers of Success Among Women Entrepreneurs. Adarsh Journal of Management Research, 9(2), 52-58.

Vadnjal, J., \& Vadnjal, M. (2013). The role of husbands: Support or barrier to women's entrepreneurial start-ups? African Journal of Business Management, 7(36), 3730.https://doi.org/10.5897/AJBM11.3040

Wanjau, K. N., Wambugu, A. W., \& Mung'atu, J. (2015). The Relationship Between Risk Taking and Performance of Small and Medium Agro Processing Enterprises in Kenya.

Weisberg, H. F., \& Bowen, B. D. (1977). Introduction to Survey Research and Data Analysis (1977). Journal of Market Research, 14, 621-622.

Welsh, D. H., \& Kaciak, E. (2018). Women's entrepreneurship: A model of business-family interface and performance. International Entrepreneurship and Management Journal, 14(3), 627-637. https://doi.org/10.1007/s11365-018-0507-6

Welsh, D. H., Memili, E., \& Kaciak, E. (2016). An empirical analysis of the impact of family moral support on Turkish women entrepreneurs. Journal of Innovation \& Knowledge, 1(1), 3-12. https://doi.org/10.1016/j.jik.2016.01.012

Winn, J. (2005). Women entrepreneurs: Can we remove the barriers? The International Entrepreneurship and Management Journal, 1(3), 381-397. https://doi.org/10.1007/s11365-005-2602-8

Yacus, A. M., Esposito, S. E., \& Yang, Y. (2019). The Influence of Funding Approaches, Growth Expectations, and Industry Gender Distribution on High-Growth Women Entrepreneurs. Journal of Small Business Management, 57(1), 59-80.

Ylinenpää, H., \& Chechurina, M. (2000). Perceptions of female entrepreneurship in Russia. Paper to be presented at EFMD 30th Small Business Seminar in Ghent. Belgium.

Zhou, H. (2010). Knowledge, entrepreneurship and performance: Evidence from country-level and firm-level studies (No. EPS-2010-207-ORG).

\section{Copyrights}

Copyright for this article is retained by the author(s), with first publication rights granted to the journal.

This is an open-access article distributed under the terms and conditions of the Creative Commons Attribution license (http://creativecommons.org/licenses/by/4.0/). 